\title{
EXPERIMENTAL ANALYSIS AND KINETIC MODELLING FOR STEAM GASIFICATION OF THE TURKISH LIGNITES
}

\author{
Ö.F. Güney ${ }^{1, *}$, A.Koyun ${ }^{1}$
}

\begin{abstract}
During the last decades, the importance of structural parameters has been increased because the models which have been developed using structural parameter can define the gasification process effectively. In this study, structural parameters, rates of conversion and activation energies of Zonguldak coal and Beypazari lignite have obtained. The samples of Zonguldak coal and Beypazari lignite used in this study have different characteristics. Pore dimensions, distribution of pores and surface areas were used as structural parameters. Suitable kinetic parameters were determined by fitting the gasification model to experimental data. The random pore model was used to define these kinetic parameters. The data were taken from experiments of Balci and Durusoy and the results obtained from Zonguldak coal and Beypazarı lignite pyrolysed in a vertical tube heated from outside by an inert gas and gasified with steam at elevated temperatures (between $700^{\circ} \mathrm{C}$ and $1000^{\circ} \mathrm{C}$ ) were used in the model.
\end{abstract}

\section{Keywords: Random Pore Model, Coal Gasification, Elevated Temperature, Porosity}

\section{INTRODUCTION}

Turkey has a considerable amount of coal reserves of which lignites constitutes a major portion with a reserve of $8.05 \times 10^{6}$ tones and mainly utilized conventionally for power production and heating purposes [1]. The studies in gasification processes are based on the coal activation energy, the rate of conversion, the amount of obtained gas, the gas compound and especially the pore lengths, the pore volume and the surface area of the coal [2-6]. These processes basically occur in two stages: The first stage is the devolatilization of coal to char, which classically occurs in the temperature range $150-800{ }^{\circ} \mathrm{C}$. The second stage is the gasification of the char with an oxidizing agent, such as steam, carbon dioxide, oxygen or a mixture of these gases at higher temperatures. The pyrolysis stage is shown major changing of the textural and molecular structure. So, pore and surface structures change very much. The second stage is relatively slow except plasma, some of the fluidized bed and free falling flow processes [1]. The data of gasification that used in this study are for the relatively slow process. Either the gasification process and its type or pyrolysis process and its type characteristics produce different significant parameters. In order to design the dimensions of a reactor, we use conversion type and kinetic parameters.

A large number of studies on the reactivity and kinetics of char have been conducted. De Micco et al. included the effect of pyrolysis temperature in the gasification reactions in their studies [7]. Liu et al. analyzed the chars at elevated temperatures, and showed all chars tendency to increase reaction rate with elevated temperatures [8,9]. Matsumoto et al. studied on steam and oxygen gasification of biomass chars [10]. Naturally, the atmosphere of the pyrolysis and gasification affects the structural parameters, which are the reason for change in the conversion rate. Everson et al. studied on $\mathrm{CO}_{2}$ gasification and properties of high ash coal-char particles derived from inertinite-rich coal [11]. Kajitani et al. studied on rate analysis of coal char gasification. In two of their samples, structural parameters were equal to 1 that means surface reactions during gasification were relatively very fast; and the other samples' structural parameters increased from 10 to 26 with the elevated temperature [12].

Various mathematical models have been developed in order to express gasification processes [13]. Levenspiel developed a volumetric pore model, in which it was assumed that the reaction occurred at all pore volumes, and also he developed shrinking pore model, in which the reaction occurred from the outside to the inside of pore and was assumed that the structure shrank during the reaction [13-15]. Bhatia et al. developed random pore model which varied depending on the structural parameters, ensuring suitability for lignite with low reactivity in terms of getting into the impact of structural features of coal, and these reactions were basically classified as assuming the occurrence from outside to inside and from inside to outside [16-20].

In this study, the structural parameters of the gasification of the Zonguldak and Beypazarı lignites were determined. The gasification results were taken from Zonguldak and Beypazarı lignites with steam gasification 
after pyrolysis of them and some of the pore characteristics of Zonguldak coal taken from an experimental study of Balci and Durusoy [21-23]. Particularly, measurements of pore characteristics were made in mercury porosimeter of Beypazarı lignite. The model parameters of Zonguldak and Beypazarı lignites have been developed using Bhatia and Perlmutter's random pore model. Suitable kinetic parameters were determined by fitting the gasification model to experimental data. The $\mathrm{R}^{2}$ values that used to evaluate the quality of the linear fit are higher than 0.95 which can be interpreted as very good fit. The activation energy and collision factor required for the gasification was determined to examine the structural and kinetic behaviors of coal during gasification.

\section{Theoretical and Experimental Study}

The general assumption of Bhatia, Perlmutter and Balci in the modeling of solid-gas reaction is that the form of reaction develops in the inner surface layer of the pores [19-23]. Models are basically divided into two classes that the reaction on the surface of non-porous particles and on the pore surfaces in the solid.

$$
L_{0}=\frac{1}{\pi} \int \frac{v(r) d r}{r^{2}}
$$

The porosity $\varepsilon_{0}$ is directly determined usually at the beginning of gasification. $\mathrm{S}_{0}$ and $\mathrm{L}_{0}$ are determined by measuring the absorption or mercury porosimetry. $\mathrm{v}(\mathrm{r}) \mathrm{can}$ be calculated from the pore volume distribution of the mercury pore volume value corresponding to each pressure on the surface measured by the mercury porosimetry. On the actual surface reaction rate is proportional to the total surface area. If we desire to express the rate of the process by means of conversion term, we can write:

$$
\begin{gathered}
X=1-\frac{m_{c}}{m_{c, 0}} \\
\frac{d X}{d t}=\frac{k_{s} C^{n} S_{0}}{1-\varepsilon_{0}}(1-X) \sqrt{1-\psi \ln (1-X)}
\end{gathered}
$$

Change of surface area at any time during the reaction can be expressed as follows [20]:

$$
\begin{gathered}
\frac{S}{S_{0}}=\frac{1-X}{\left(1-\frac{\tau}{\sigma}\right)^{3}} \sqrt{1-\psi \ln \frac{1-X}{\left(1-\frac{\tau}{\sigma}\right)^{3}}} \\
\tau=\frac{k_{S} C^{n} S_{0}}{1-\varepsilon_{0}} \text { and } \sigma=\frac{R_{0} S_{0}}{1-\varepsilon_{0}}
\end{gathered}
$$

The particle diameters of lignites and surface area are highly large which means $\sigma$ is infinite, so the Eq. 4 becomes:

$$
\frac{s}{s_{0}}=(1-X) \sqrt{1-\psi \ln (1-X)}
$$

Total conversion expression that depends structural parameter is:

$$
X_{\text {total }}=1-\left(1-\frac{\tau}{\sigma}\right)^{3} \exp \left(-\tau\left(1-\frac{\tau \psi}{4}\right)\right)
$$




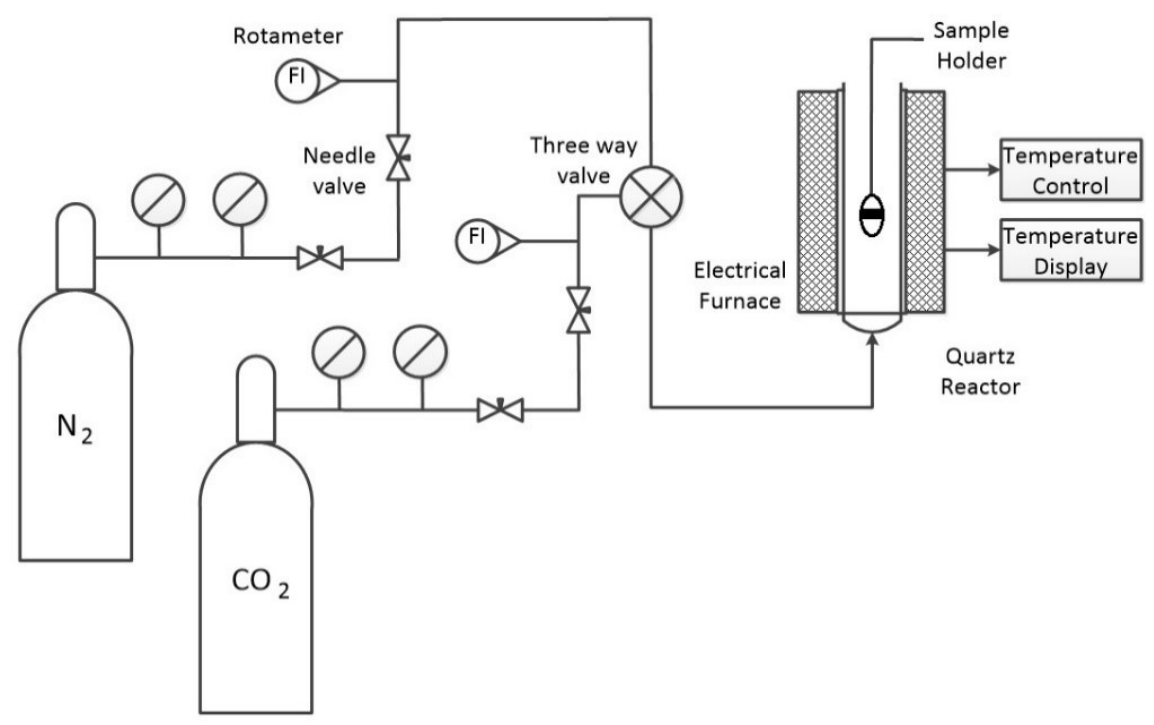

Figure 1. Experimental setup schematic

Experiments are performed in a quartz tubular reactor which is placed into a tubular electrical furnace. The furnace is adjustable to the desired isothermal temperature by using a temperature controller. The sample is placed into a platinum mesh sample holder, then it is hung into the hot reactor where the reactant gas passes. Nitrogen is used to stop the gasification reaction and to cool the reacted sample. Experimental setup diagram can be shown in Fig. 1. The coal samples used in the experiments are brought from Zonguldak and Beypazarı lignites. Some parameters and elemental analyses of the samples are given in Table 1 and ash analyses of the samples are given in Table 2. The pore volume distribution in terms of the pore diameter was first found by the Gaussian distribution function. The surface area, pore length, pore diameter and density used to produce model parameters for conversion temperatures.

Table 1. The proximate and elemental analyses of the samples

\begin{tabular}{|l|l|l|}
\hline Proximate Analysis & Zonguldak Coal & Beypazarı Coal \\
\hline Moisture & 0.46 & 15.20 \\
\hline Volatile Matter & 30.20 & 27.58 \\
\hline Fixed Carbon & 55.96 & 23.82 \\
\hline Ash & 13.38 & 33.40 \\
\hline Ultimate Analysis & & \\
\hline Carbon & 61.94 & 34.18 \\
\hline Hydrogen & 3.69 & 2.26 \\
\hline Nitrogen & 18.85 & 1.60 \\
\hline Sulfur & 0.46 & 1.78 \\
\hline Oxygen & 4.68 & 21.73 \\
\hline Ash & 13.38 & 38.47 \\
\hline
\end{tabular}

Table 2. Composition of the Ash

\begin{tabular}{|c|c|c|}
\hline Compound & Zonguldak Coal & Beypazarı Coal \\
\hline $\mathrm{SiO}_{2}$ & 48.55 & 44.8 \\
\hline $\mathrm{Al}_{2} \mathrm{O}_{3}+\mathrm{TiO}_{2}$ & 29.8 & 13.5 \\
\hline $\mathrm{Fe}_{2} \mathrm{O}_{3}$ & 6.59 & 11.8 \\
\hline $\mathrm{CaO}$ & 5.41 & 9.8 \\
\hline $\mathrm{Na}_{2}+\mathrm{K}_{2} \mathrm{O}$ & 3.61 & 6.6 \\
\hline $\mathrm{MgO}$ & 1.87 & 6.5 \\
\hline
\end{tabular}


Pore analyses of the samples and structural analyses of the samples are given in Tables 3 and 4.

Table 3. Pore analyses of the samples

\begin{tabular}{|c|c|c|c|c|}
\hline & \multicolumn{3}{|c|}{ Pore volume $/ \mathrm{cm}^{3} \mathrm{~g}^{-1}$} & Total $/ \mathrm{cm}^{3} \mathrm{~g}^{-1}$ \\
\hline Coal Sample & $>50 \mu \mathrm{m}$ & $50-1 \mu \mathrm{m}$ & $<1 \mu \mathrm{m}$ & \\
\hline Beypazarı & 0.028 & 0.0517 & 0.1589 & 0.2386 \\
\hline Zonguldak@800 ㄷ & 0 & 0.1905 & 0.1171 & 0.3074 \\
\hline Zonguldak@900C & 0 & 0.1417 & 0.1059 & 0.2786 \\
\hline Zonguldak@1000 ㄷ & 0 & 0.1085 & 0.0783 & 0.2387 \\
\hline Zonguldak@1100C & 0 & 0.0869 & 0.0661 & 0.1498 \\
\hline
\end{tabular}

Table 4. Structural Analyses of the samples

\begin{tabular}{|c|c|c|c|c|c|c|c|}
\hline & $\mathbf{e}_{0}$ & $\mathrm{~L}_{0} \cdot 10^{12}$ & $\mathbf{S}_{\mathbf{0}}$ & $d_{\text {pore.avg }}$ & $d_{\text {pore }}$ & $\rho$ & $\psi$ \\
\hline Coal Sample & & $\mathrm{cm} \mathrm{cm}^{-3}$ & $\mathrm{~cm}^{2} \mathrm{~g}^{-1}$ & $\mu \mathrm{m}$ & $\mathbf{m m}$ & $\mathrm{cm}^{3} \mathrm{~g}^{-1}$ & \\
\hline Beypazarı & 0.313 & 0.7308 & 109899 & 60.2 & 3.0 & 1.9126 & 13.9 \\
\hline Zonguldak@800 C & 0.323 & 27.988 & 16300 & 2.39 & 2.6 & 1.0513 & 6.46 \\
\hline Zonguldak@900 ㄷ & 0.296 & 27.988 & 12700 & 2.34 & 2.6 & 1.0628 & 13.7 \\
\hline Zonguldak@1000 ㄷ & 0.257 & 28.019 & 12625 & 2.51 & 2.6 & 1.0811 & 13.9 \\
\hline
\end{tabular}

Coal gasification is a heterogeneous reaction. Porosity and pore surface area are very important parameters for the characterization of the reaction. Depending on increasing pyrolysis temperature and pyrolysis time, pore size decreases that reactivity of coal also simultaneously decreases. The highest porosity occurs from 750 to $850{ }^{\circ} \mathrm{C}$. The reactivity is more dependent upon the heat treatment conditions than the type of coal at high temperature over $700^{\circ} \mathrm{C}$.

\section{RESULTS AND DISCUSSION}

The data are taken from studies of Balcı and Durusoy, and also measured characteristics in this study are combined. The kinetic characteristics are extracted via using model. The results obtained from the conversion value of the gasification process using 50\% conversion time in Eq. 3; after that $\tau$ and $\psi$ values are calculated. The same procedure performed for the other temperatures drawn Arrhenius curve, $\mathrm{k}_{0}$ and $\mathrm{E}$ values are determined. $\tau$ and $\psi$ parameters obtained from experimental data are given in Table 5.

Table 5. Experimental $\tau$ and $\psi$ parameters

\begin{tabular}{|l|l|l|}
\hline Coal Type & $\boldsymbol{\psi}$ & $\boldsymbol{\tau}$ \\
\hline Beypazar1 @700 ${ }^{\circ} \mathrm{C}$ & 3.73 & $2.214 \times 10^{-4}$ \\
\hline Beypazar1 @800 ${ }^{\circ} \mathrm{C}$ & 4.21 & $2.851 \times 10^{-4}$ \\
\hline Beypazar1 @900 ${ }^{\circ} \mathrm{C}$ & 9.57 & $3.378 \times 10^{-4}$ \\
\hline Beypazar1@1000 ${ }^{\circ} \mathrm{C}$ & 11.5 & $7.001 \times 10^{-4}$ \\
\hline Zonguldak@800 ${ }^{\circ} \mathrm{C}$ & 1.41 & $4.321 \times 10^{-4}$ \\
\hline Zonguldak @900 $90{ }^{\circ} \mathrm{C}$ & 1.01 & $2.308 \times 10^{-4}$ \\
\hline Zonguldak @ $1000^{\circ} \mathrm{C}$ & 0.861 & $4.511 \times 10^{-4}$ \\
\hline
\end{tabular}

As shown in Fig. 2 and 3, the experimental data have been successfully adopted into the model. Conversion curves drawn by using $\psi$ parameters obtained from experimental results and calculated from Eq. 6 by using $\psi$ parameters given in Table 4 are shown together in Figs. 2 and 3. $\sigma$ is infinite $(\sigma \rightarrow \infty)$, because the particle diameters of lignites and surface area are highly large. For that reason, $\sigma$ and $\tau$ parameters have been neglected used in Eq. 6. 


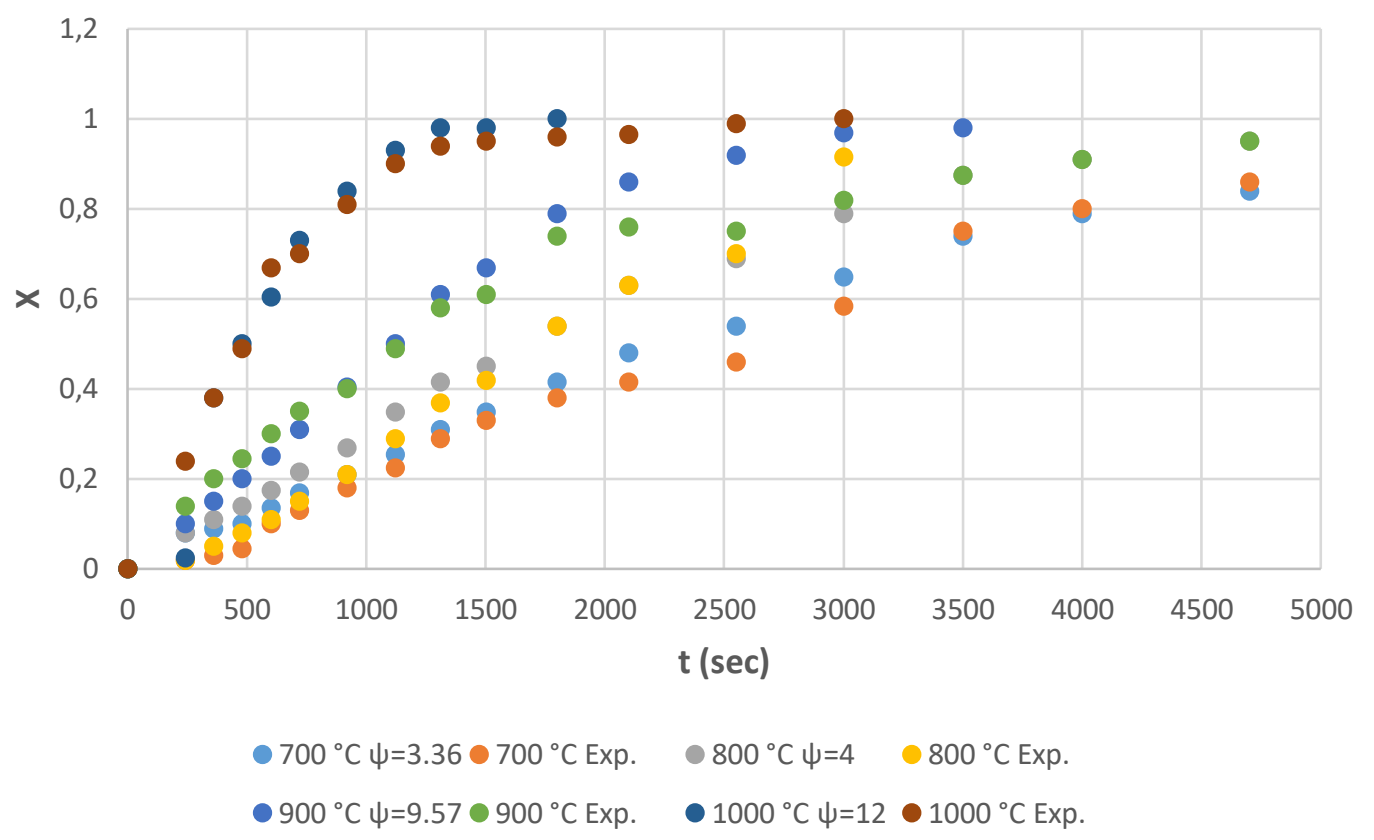

Figure 2. Carbon Conversion - Time figure for Beypazarı Lignite

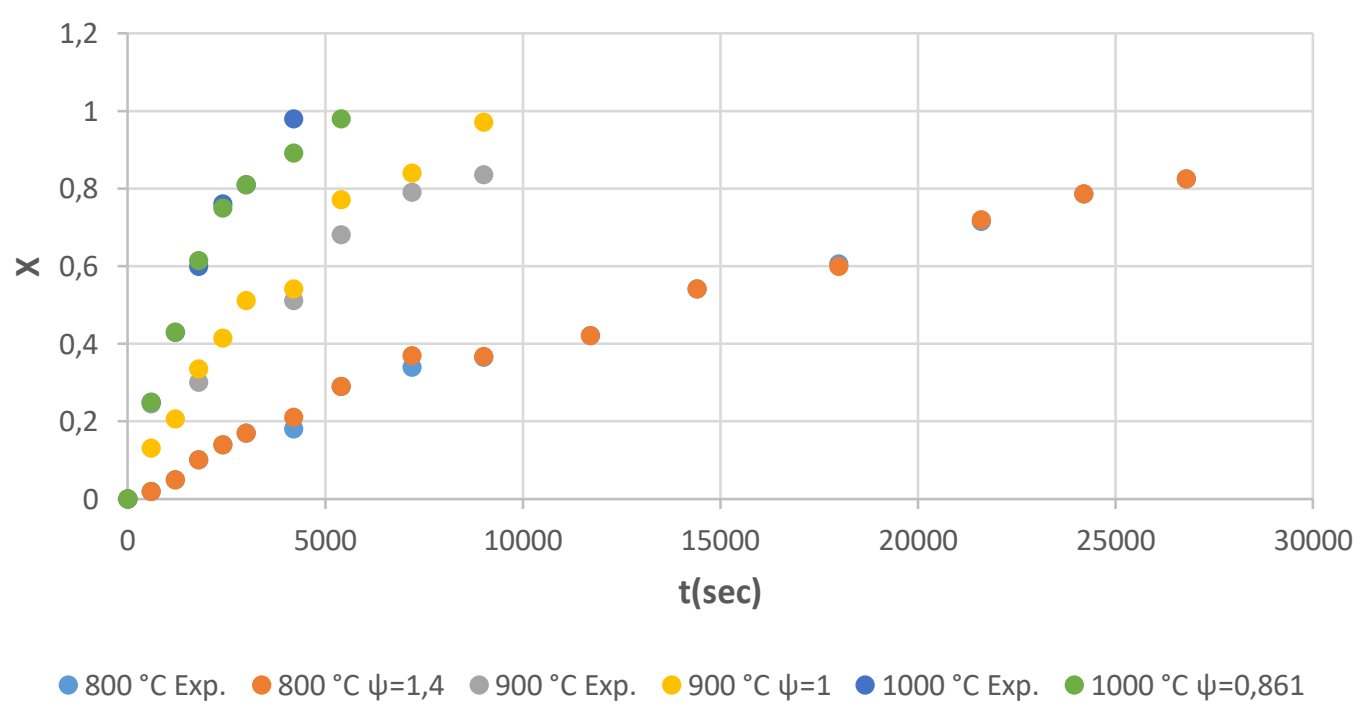

Figure 3. Carbon Conversion - Time figure for Zonguldak Lignite

Accordingly, the dimensionless time for $50 \%$ conversion for using $\psi$ values particle parameter $\sigma$ is given in Fig. 4. As shown in Fig. 4, there is no significant change in conversion for $\sigma>100$ condition. In fact, it can be concluded that the outer surface area of the particles is negligible compared with the internal surface area. As also seen in Fig. 4, there is an adverse effect that the reaction time in sufficiently small particles is independent from internal structure for $\psi<100$. In the transition region the inner surface area and outer surface area are comparable in terms of impact. In cases where the outer surface is very small, $\sigma$ parameter is ignored because it is very high, so that the conversion curve can be drawn only by using $\psi$ parameters. Here, the rate (slope) usually decreases with time. In cases where the $\psi$ parameter is very small, pore walls are closed and the total surface area is reduced as the reaction proceeds. With the high $\psi$ values, this event is delayed because of relatively high conversion curves. 


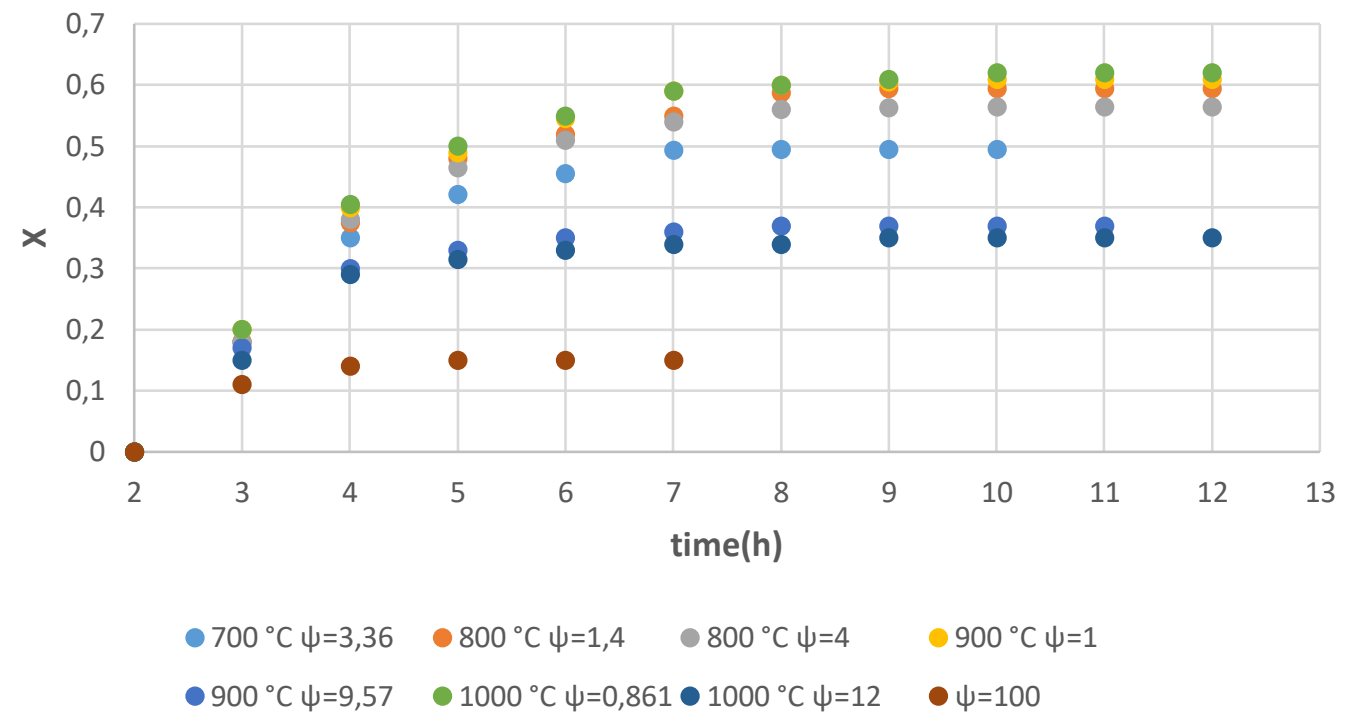

Figure 4. Required time for $\% 50$ conversion for different $\psi$ parameters

With respect to the surface area change during the reactions; as determined from Eq. 3 and using $\psi$ values in Table 5, the change in pore surface area during the conversion obtained from experimental data are given in Figs. 5 and 6.

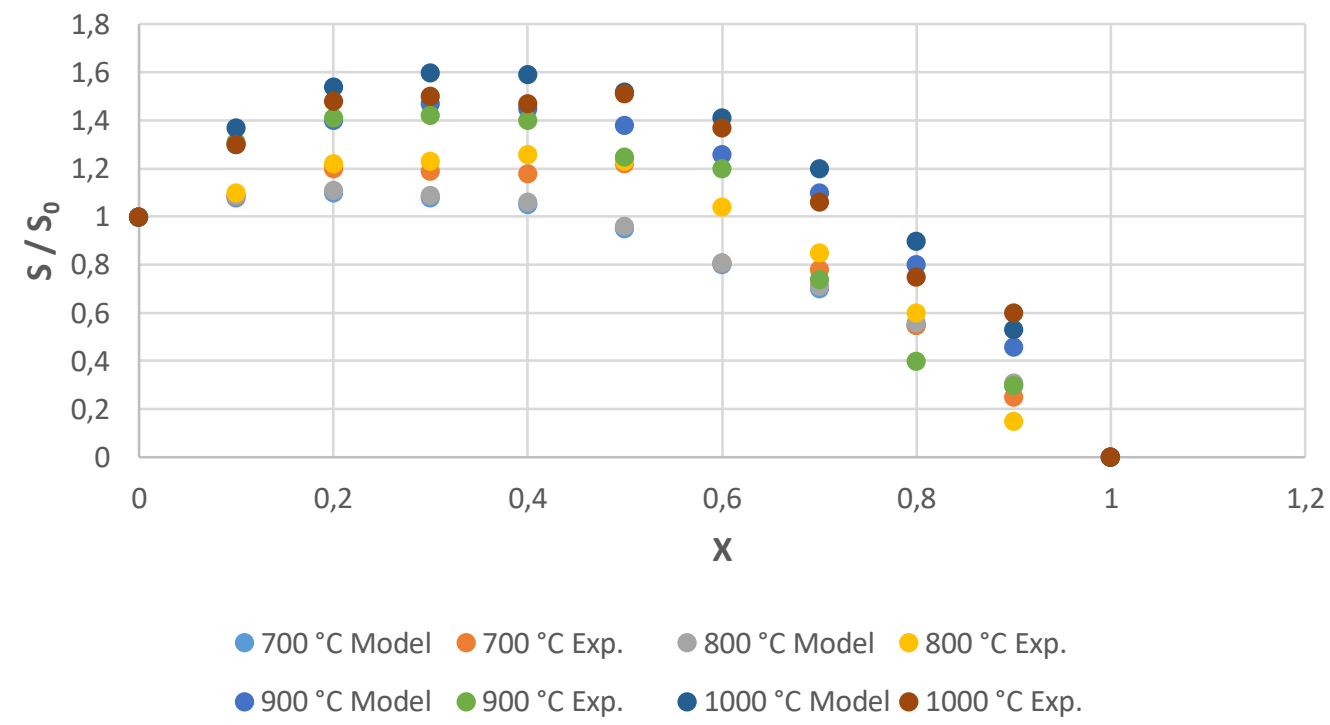

Figure 5. Change of pore surface area for Beypazarı lignite

Micco et al. studied the gasification reactions by including the effect of pyrolysis temperature [7]. Although their analyzed samples are very similar to Zonguldak char, $\psi$ parameters showed differences because of the different ash structure and pore surface volumes [7]. Matsumoto and his colleagues studied on steam and oxygen gasification of biomass chars, and their samples are very similar to ours, moreover, structural parameters and conversion rates are very close when comparing experimental results with ours [10]. Bhatia and Perlmutter studied the behavior of pores during the gasification of coal and characterized the dependency of the porosity of the coal structure on the structural parameter values that vary the change rate of reaction $[19,20]$. 


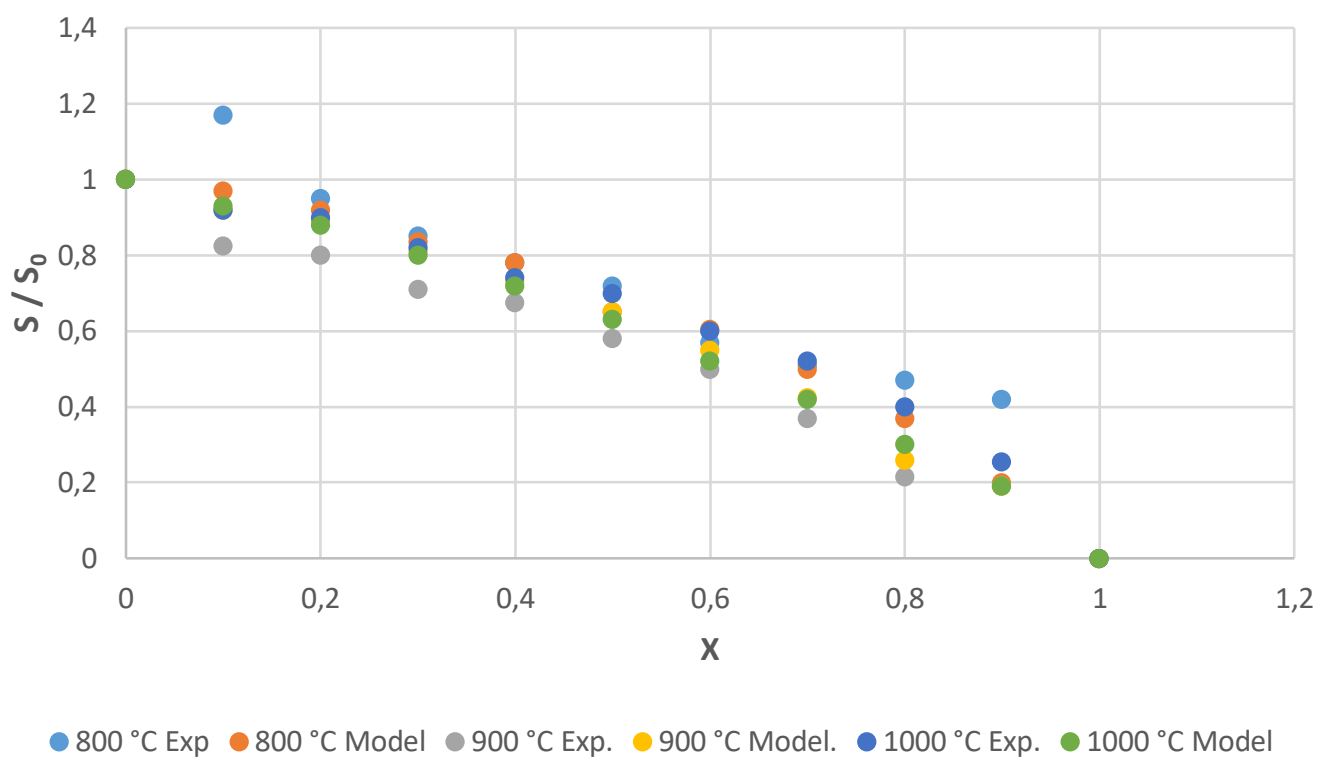

Figure 6. Change of pore surface area for Zonguldak lignite

The overall effect during the reaction for high $\psi$ values; as seen from Figs. 5 and 6 is carried out in the direction of growth of the pores and reaction surfaces. Using Eq. 6 for $\sigma \rightarrow \infty$, we write;

$$
X_{\max }=1-\frac{\exp (2-\psi)}{2 \psi}
$$

Using Eq. 8, the maximum conversion rate takes place around $0<\mathrm{Xm}<0.393$ for $2<\psi<\infty$. The highest change values are given in Table 4. As seen in Figs. 5 and 6, in advanced stages of conversion, the rate goes through the highest point for $\mathrm{X}=0.36$ and 0.30 values, respectively. Here, the role of the diffusion event is clearly defined and the kinetically controlled conversion stage in the pore generation area was studied. The compliance at high temperatures that we observed at the conversion curve strengthened but small deviations in the model seemed to start at low temperatures. These deviations can also be caused by the diffusion event being more active at low temperatures for small co-particle diameter.

Conversion curves which are drawn according to the $\psi$ parameters obtained for both types of lignites are $1-9 \%$ higher than the experimental results. In this case, also examining the impact of the diffusion for conversion would be useful to perform additional tests for different particle diameters at the same temperature for the same coal. The model provides a better fit for Beypazari lignite than for Zonguldak lignite. Reaction rate values have been identified between $0.55-5.5 \times 10^{-4} \mathrm{~s}^{-1}$ in the literature for various types of coal which have suddenly been hydropyrolysed. The parameters for both lignites are given in Table 6 .

Table 6. Surface reaction rates and its parameters for particle pore model

\begin{tabular}{|l|l|l|l|l|}
\hline Coal Type & $\mathbf{k}_{\mathbf{s}}$ & $\mathbf{k}_{\mathbf{0}}$ & $\mathbf{E}$ & $\mathbf{m}$ \\
\hline Beypazar1@700 ${ }^{\circ} \mathrm{C}$ & $1.41 \times 10^{-4}$ & $4.01 \times 10^{6}$ & 66.35 & 0.44 \\
\hline Beypazar1@800 ${ }^{\circ} \mathrm{C}$ & $2.37 \times 10^{-4}$ & & & 0.174 \\
\hline Beypazar1@900 ${ }^{\circ} \mathrm{C}$ & $3.38 \times 10^{-4}$ & & & 0.40 \\
\hline Beypazar1@1000 $\mathrm{C}$ & $10.5 \times 10^{-4}$ & & & 0.15 \\
\hline Zonguldak@800 ${ }^{\circ} \mathrm{C}$ & $1.86 \times 10^{-4}$ & $2.45 \times 10^{10}$ & 162.64 & 0.35 \\
\hline Zonguldak@900 ${ }^{\circ} \mathrm{C}$ & $4.81 \times 10^{-4}$ & & & 0.32 \\
\hline Zonguldak@1000 ${ }^{\circ} \mathrm{C}$ & $5.44 \times 10^{-4}$ & & & 0.60 \\
\hline
\end{tabular}


For constant reagent concentration conditions, the char gasification rate is dependent on temperature according to the Arrhenius relationship. The kinetic constant $\mathrm{k}$ is described by the well-known Arrhenius' equation given in Eq. 9 [24-31];

$$
k=k_{0} e^{-E_{a} / R T}
$$

Initial gasification rate decreases, whereas $\psi$ values indicate an increase and large $\psi$ parameters are due to the presence of low microporosity in char. Considering the experimental data; Beypazari char's pores mostly in pore diameter are below 1 micron, while Zonguldak char pores' are above 1 micron of pore diameter at each temperature. Although this case is consistent with the $\psi$ parameters obtained from the test results, it is not consistent with the values calculated from Eq. 4. On the other hand, we observed that the rate change of decreasing reactivity in Zonguldak lignite was due to increasing pyrolysis temperature, and the catalytic effect likely from the ashes in Beypazarı lignite increased the reactivity and the rate despite the microporosity.

Using Arrhenius' equation, the rate constants are calculated as follows:

- For Zonguldak lignite;

$\mathrm{k}_{0}=2.445 \times 10^{10} \mathrm{~s}^{-1}$, and activation energy $\mathrm{E}=162.64 \mathrm{~kJ} \mathrm{~mol}^{-1}$, thus $\mathrm{k}_{\mathrm{s}}=2.445 \times 10^{10} \cdot \mathrm{e}^{-7.984 \mathrm{~T}}$,

- For Beypazarı lignite;

$\mathrm{k}_{0}=4.018 \times 10^{10} \mathrm{~s}^{-1}$, and activation energy $\mathrm{E}=66.38 \mathrm{~kJ} \mathrm{~mol}^{-1}$, thus $\mathrm{k}_{\mathrm{s}}=4.018 \times 10^{10} . \mathrm{e}^{-19.562 \mathrm{~T}}$

For both lignites, Arrhenius curve that defines the rate is shown in Fig. 7. Particularly, two segment curves observed in Beypazari lignite may also result from the catalytic effect caused by the ash in the gasification process.

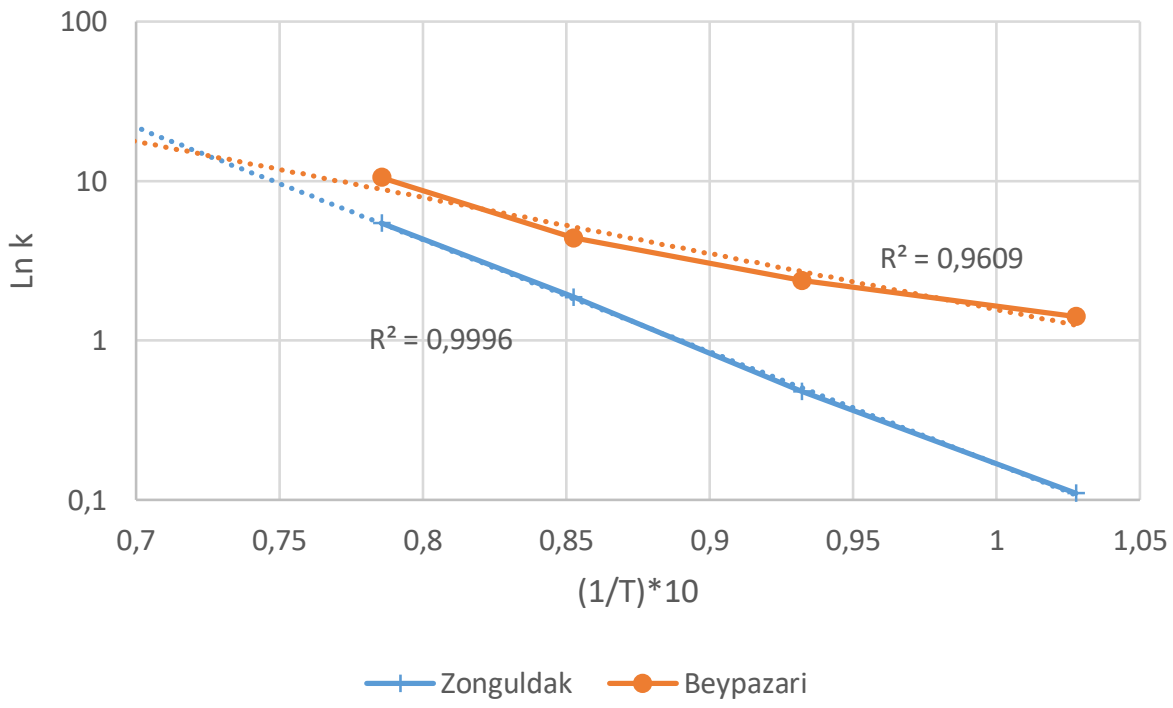

Figure 6. Rate expression with Arrhenius plots

It is observed that all the data points fall within a narrow band with minor differences around the slopes of the fitting lines. The specific values of activation energy for the three different chars were calculated from these slopes, which are tabulated in Table 6 . The activation energies in this study (around 162 and $66 \mathrm{~kJ} / \mathrm{mol}$ ) are different from each other for the same kind of chars, which may be caused by the different ash contents in chars. Also, Jayaraman and his colleagues' study about estimation of synergetic effects of steam gasification for a similar type of Turkish coal [26]. In a different study about steam gasification of Victorian brown coal chars, activation energies are very similar to Zonguldak char while the compositions of the chars are very similar [27].

As a result, the activation energy and collision factor values can be found from the proposed equations by conducting kinetic studies. As well as the model also includes the highest porosity equation about how much of coal conversion that takes place. It even has the ability to adapt quickly to the diffusion kinetics control based cases. However, the model is applied to low-valance lignite moving away from the experimental data, over $60 \%$ 
conversion. In the model of Bhatia and Perlmutter, the structural parameters occurring randomly placed in 3D (three-dimensional) space axis could be evaluated with the description of 3D pore shape.

\section{CONCLUSION}

In this study, the structural parameters of the gasification of the Zonguldak and Beypazarı lignites were determined. The coefficient of determination $\mathrm{R}^{2}$ was used to evaluate the quality of the linear fit, and the results show that all $\mathrm{R}^{2}$ values are higher than 0.95 which can be interpreted as very good fit. The model parameters of Zonguldak and Beypazarı lignites have been developed using the random pore model. The activation energy and collision factor required for the gasification was determined to examine structural and kinetic behaviors of coal during gasification as well. Kinetic studies have been conducted for the gasification process, particularly the classical models like particle and shrinking core ones, which cannot accurately determine the gasification of low valance lignites' activation energy and frequency of collisions due to determining the inaccurate reaction rate, because the reaction rates decrease depending on the reaction progress according to the models except for the random pore model. However, looking at the experimental results, the reaction rate remained at the highest point even though the reaction proceeds in time during gasification of the low-valance lignites. Due to this reason, Bhatia and Perlmutter developed a model that highlighted pore structure features. In their model, the coal structure defined by a particular structure parameter containing particle sizes and the pore structure parameters incorporating the features, such as coal porosity, reaction surface area and pore lengths. Because of the deviation of the coal beyond the $60 \%$ conversion on the conversion-time curves obtained from the gasification experiments using this model, a new model can be developed including again structural variables as a future work.

\section{NOMENCLATURE}

$\begin{array}{ll}E & \text { Activation energy } \\ \mathrm{k}_{\mathrm{s}} & \text { Reaction rate constant } \\ \mathrm{L}_{0} & \text { Pore length per unit volume } \\ \mathrm{m}_{\mathrm{c}} & \text { Mass } \\ \mathrm{r}_{\mathrm{s}} & \text { Reaction rate } \\ \mathrm{S}_{0} & \text { Initial surface area } \\ \mathrm{R} & \text { Ideal gas constant } \\ \mathrm{v}(\mathrm{r}) & \text { Pore volume distribution } \\ \mathrm{X} & \text { Fractional conversion of carbon } \\ \varepsilon_{0} & \text { Initial porosity } \\ \sigma & \text { Layer thickness in solid } \\ \tau & \text { Dimensionless time } \\ \psi & \text { Structural parameter } \\ \mathrm{T} & \text { Reaction temperature }\end{array}$

\section{REFERENCES}

[1] Gaye ÖÇ, Hayrettin Y, Gürüz AG. Physical and chemical properties of selected Turkish lignites and their pyrolysis and gasification rates determined by thermogravimetric analysis. J. Anal. Appl. Pyrolysis; 2007;80:262-268. https://doi.org/10.1016/j.jaap.2007.03.005

[2] Zhang Y, Ashizawa M, Kajitani S, Miura K. Proposal of a semi-empirical kinetic model to reconcile with gasification reactivity profiles of biomass chars. Fuel 2008;87:475-481.

[3] Watanabe H, Otaka M, Numerical simulation of coal gasification in entrained flow coal gasifier. Fuel 2006;85:1935-1943. https://doi.org/10.1016/j.fuel.2007.04.026

[4] Zou JH, Zhou ZJ, Wang FC, Zhang W, Dai ZH, Liu HF, Yu ZH. Modeling reaction kinetics of petroleum coke gasification with CO2. Chemical Eng. and Proc. 2007;46:630-636. https://doi.org/10.1016/j.cep.2006.08.008

[5] Xu S, Zhou Z, Gao X, Yu G, Gong X. The gasification reactivity of unburned carbon present in gasification slag from entrained-flow gasifier. Fuel 2009;90:1062-1070. https://doi.org/10.1016/j.fuproc.2009.04.006 
[6] Fermoso J, Arias B, Pevida C, Plaza MG, Rubiera F, Pis JJ. Kinetic Models Comparison for Steam Gasification of Different Nature Fuel Chars. Journal of Thermal Analysis and Calorimetry, 2008;91:779786. https://doi.org/10.1007/s10973-007-8623-5

[7] De Micco G, Nasjleti A, Bohé AE. Kinetics of the gasification of a Rio Turbio coal under different pyrolysis temperatures. Fuel 2012;95:537-543. https://doi.org/10.1016/j.fuel.2011.12.057

[8] Liu TF, Fang YT, Wang Y. An experimental investigation into the gasification reactivity of chars prepared at high temperatures. Fuel 2008;87:460-466. https://doi.org/10.1016/j.fuel.2007.06.019

[9] Liu H, Luo C, Kato S, Uemiya S, Kaneko M, Kojima T. Kinetics of CO2/Char gasification at elevated temperatures Part I: Experimental results. Fuel Processing Technology 2006;87:775-781.

[10] Matsumoto K, Takeno K, Ichinose T, Ogi T, Nakanishi M. Gasification reaction kinetics on biomass char obtained as by-product of gasification in an entrained-flow gasifier with steam and oxygen at 900-1000 ${ }^{\circ}$ C. Fuel 2009;88:519-527. https://doi.org/10.1016/j.fuel.2008.09.022

[11] Everson RC, Neomagus HW, Kaitano R, Falcon R, Van Alphen C, Cann V. Properties of high ash coalchar particles derived from inertinite-rich coal: II. Gasification kinetics with carbon dioxide. Fuel 2008;87:3403-08. https://doi.org/10.1016/j.fuel.2008.05.019

[12] Kajitani S, Suzuki N, Ashizawa M, Hara S. CO2 gasification rate analysis of coal char in entrained flow coal gasifier. Fuel 2006;85:163-169. https://doi.org/10.1016/j.fuel.2005.07.024

[13] Mandapati RN, Daggupati S, Mahajani SM, Aghalayam P, Sapru RK, Sharma RK, Ganesh A. Experiments and kinetic modeling for $\mathrm{CO} 2$ gasification of Indian coal chars in the context of underground coal gasification. Industrial \& Engineering Chemistry Research 2012;51:15041-52. https://doi.org/10.1021/ie3022434

[14] Levenspiel O. Chemical Reaction Engineering, 3rd ed. Wiley: New York; 1998;41-42

[15] Levenspiel O. Chemical Reaction Engineering, 3rd ed. Wiley: New York; 1998;575-576.

[16] Gupta JS, Bhatia SK. A modified discrete random pore model allowing for different initial surface reactivity. Carbon 2000;38:47-58. https://doi.org/10.1016/S0008-6223(99)00095-0

[17] Feng B, Bhatia SK. On the validity of thermogravimetric determination of carbon gasification kinetics. Chemical Engineering Science 2002;57:2907-2920. https://doi.org/10.1016/S0009-2509(02)00189-6

[18] Feng B, Bhatia SK. Variation of the pore structure of coal chars during gasification. Carbon 2003;41:507523. https://doi.org/10.1016/S0008-6223(02)00357-3

[19] Bhatia SK, Perlmutter DD. A random pore model for fluid solid reactions: part I. Isothermal, kinetic control. AIChE Journal 1980;26:379-86.

[20] Bhatia SK, Perlmutter DD. A random pore model for fluid solid reactions: part II. Diffusion and transport effects. AIChE J. 1981;27:247-254.

[21] Koyun A. Pyrolysis and gasification of low valence Turkish lignites. PhD Thesis, Turkey, 1992.

[22] Durusoy T. Turkey, Examination of the carbonization product of some Turkish lignite. PhD Thesis, 1989.

[23] Balc1 S. Turkey, Kinetics of activated carbon production from almond shell, hazelnut shell and beech wood and characterization of products. PhD Thesis, 1985.

[24] Keller F, Küster F, Meyer B. Determination of coal gasification kinetics from integral drop tube furnace experiments with steam and CO2. Fuel 2018;218:425-438. https://doi.org/10.1016/j.fuel.2017.11.120

[25] Gao X., Zhang Y, Li B, Zhao Y, Jiang B. Determination of the intrinsic reactivity for carbon dioxide gasification of rice husk chars using random pore model. Bioresource technology 2016;218:1073-1081. https://doi.org/10.1016/j.biortech.2016.07.057

[26] Jayaraman K, Gökalp I, Jeyakumar S. Estimation of synergetic effects of CO2 in high ash coal-char steam $\begin{array}{llll}\text { gasification. } & \text { Applied } & \text { Thermal } & \text { Eng. }\end{array}$ https://doi.org/10.1016/j.applthermaleng.2016.09.011

[27] Tanner J, Bhattacharya S. Kinetics of CO2 and steam gasification of Victorian brown coal chars. Chemical Engineering Journal 2016;285,331-340. https://doi.org/10.1016/j.cej.2015.09.106

[28] Samdani G, Ganesh A, Aghalayam P, Sapru, RK, Mahajani S. Kinetics of heterogeneous reactions with coal in context of underground coal gasification. Fuel 2017;199,102-114. https://doi.org/10.1016/j.fuel.2017.02.088

[29] Prabhakar A, Sadhukhan AK, Kamila, B, Gupta P. Modeling and Experimental Studies on CO2 Gasification of Coal Char Particle. Energy \& Fuels 2017;31(3):2652-2662. https://doi.org/10.1021/acs.energyfuels.6b03241

[30] Coetzee GH, Sakurovs R, Neomagus HW, Everson RC, Mathews JP, Bunt JR. Particle size influence on the pore development of nanopores in coal gasification chars: From micron to millimeter particles. Carbon 2017;112: 37-46. https://doi.org/10.1016/j.carbon.2016.10.088

[31] Gouws SM, Neomagus HW, Roberts DG, Bunt JR, Everson RC. The effect of CO2 partial pressure on the gasification rate and pore development of Highveld coal chars at elevated pressures. Fuel Processing Technology 2018;179:1-9. https://doi.org/10.1016/j.fuproc.2018.05.027 